\title{
CD83 is locally regulated and differentially expressed in disturbed murine pregnancy
}

\author{
Rebekka Einenkel, Katrin Regina Helene Packhäuser, Jens Ehrhardt, Anne Tüngler, \\ Marek Zygmunt and Damián Oscar Muzzio \\ Department of Obstetrics and Gynecology, Research Laboratory, University of Greifswald, Greifswald, Germany \\ Correspondence should be addressed to D O Muzzio; Email: damian.muzzio@med.uni-greifswald.de
}

\begin{abstract}
Alterations in the immunologic balance during pregnancy have been associated with poor pregnancy outcomes. The underlying mechanisms are complex and mouse models delivered valuable information on inflammatory imbalance in disturbed pregnancies and served as model to test potential anti-inflammatory therapies. CD83 is a transmembrane protein (mCD83) with a soluble form (sCD83) which possesses strong anti-inflammatory properties. During murine pregnancy, upregulated mCD83 expression induces sCD83 release after in vitro stimulation with LPS, phorbol myristate acetate (PMA) and ionomycin. The release mechanism of sCD83 and its control are yet to be elucidated. In this study, the expression of mCD83 and sCD83 has been extensively studied in the $\mathrm{CBA} / \mathrm{J} \times \mathrm{DBA} / 2 \mathrm{~J}$ mouse model of pro-inflammatory-mediated pregnancy disturbances. mCD83 was higher expressed on splenic B cells, uterus-draining lymph nodes T cells and dendritic cells from mice with poor pregnancy outcome (PPOM) compared to mice with good pregnancy outcome (GPOM). PPOM, however, was accompanied by lower SCD83 serum levels. In vitro treatment of splenic B cells with progesterone led to a reduction of TIMP1 expression, mCD83 expression and sCD83 release, while TIMP1 treatment had a positive effect on sCD83 availability. These results suggest that tissue and matrix components are involved in the regulation of CD83 in murine pro-inflammatory pregnancies.

Reproduction (2019) 158 323-333
\end{abstract}

\section{Introduction}

During pregnancy, the maternal immune system is confronted by the presence of paternal antigens expressed by the semi-allogeneic fetus. In order to avoid fetal rejection, the maternal immune system undergoes several adaptations. Maternal tolerance is orchestrated by a number of different mechanisms regulated by pregnancy hormones and trophoblast to shift decidual immune cells to their regulatory pendants, affecting systemic immune responses as well. Consequently, pregnant women, although not considered immunosuppressed, respond differently for example to viral infections like influenza or auto-antigens compared to non-pregnant women (Piccinni et al. 2016, Racicot \& Mor 2017).

One major challenge of the immune system during pregnancy is to provide protection against infections despite the tolerogenic shift that immune cells undergo at the fetomaternal interface. This phenomenon is achieved by the interplay of both leukocytes and soluble factors that contribute to finely balance of both immune aspects. An imbalance of pro- and anti-inflammatory components represents a risk that threatens different aspects of pregnancy health. As a result, pregnancy complications, like preterm birth, preeclampsia, intrauterine growth restriction (IUGR) and recurrent pregnancy loss arise (Raghupathy et al. 2012, Kuon et al. 2015, Harmon et al. 2016).

Mouse models contributed to an improved understanding of the ongoing processes during pregnancy. Thereby, it was shown that a general proinflammatory immune reaction, but not necessarily against paternal antigens, contributes to fetal resorption (Robertson et al. 2007). Moreover, new therapy approaches were first tested in mouse models, for example the adoptive transfer of leukocytes (DCs, B10 cells, Tregs) and soluble factors (IH-lg, IL10, TGFB) which contribute to the essential immune balance and decreased fetal resorption (Clark 2016).

Recently, we suggested that the soluble form of the transmembrane molecule CD83 (sCD83) could represent an important factor contributing to pregnancy maintenance (Packhäuser et al. 2017). Anti-inflammatory properties of sCD83 have been extensively examined in mouse models of autoimmunity, allograft transplantation and inflammatory disease (Lan et al. 2010, Bock et al. 2013, Starke et al. 2013, Eckhardt et al. 2014, Lin et al. 2018). However, it remains unclear if sCD83 is generated by alternative splicing or from shedding of the transmembrane form (mCD83) by proteases, as in the case of other immune-related factors (TGFA, TNFA, TACl, etc.) (Murphy 2008, Hoffmann et al. 2015). 
Although the function of mCD83 still remains under elucidation, different roles have been proposed depending on the cell type expressing it. On dendritic cells (DCs), mCD83 marks mature cells and is necessary for a proper $\mathrm{T}$ cell activation and co-stimulation (Zhou \& Tedder 1995, 1996, Prechtel \& Steinkasserer 2007). mCD83 is also expressed by activated T cells. CD83 silencing in $\mathrm{CD}^{+} \mathrm{T}$ cells in mice results in defective functions like antigen presentation, cytokine secretion and proliferation (Su et al. 2009). However, the overexpression of $\mathrm{mCD} 83$ in naive murine $\mathrm{CD}^{+}$ $\mathrm{T}$ cells results in FOXP3 upregulation characteristic for regulatory T cells (Reinwald et al. 2008).

mCD83 expression on B cells influences their maturation in the spleen, impacting on the marginal zone (MZ)/follicular zone (FO) B cell relative numbers (Luthje et al. 2008, Krzyzak et al. 2016). Furthermore, mCD83 expression on B cells is associated to B cell anti-inflammatory responses, including higher IL10 production (Kretschmer et al. 2007). Both, MZ/FO ratio and B cell-derived IL10 are increased in murine pregnancies and altered in pathological mouse models of pregnancy (Jensen et al. 2013, Muzzio et al. 2014a, 2016).

B cells upregulate $\mathrm{mCD} 83$ expression after stimulation with stimulatory agents such as lipopolysaccharide (LPS) and PMA. Additionally, direct cell contact plays an important role in the induction of mCD83 expression, as in the case of CD40/CD40L interactions between $B$ cells and $\mathrm{CD}^{+}{ }^{+} \mathrm{T}$ cells (Kretschmer et al. 2011). In our previous work, we showed that splenic B cells from advanced pregnancies were the most reactive to LPS stimulation in vitro. In vivo, however, the highest mCD83 expression on splenic B cells during gestation was observed at mid-pregnancy. We postulate that the compartmentation of the B cells plays an important role regulating CD83 availability during pregnancy. To test our hypothesis, we used a mouse model of systemic inflammation-induced pregnancy disturbance.

On the one hand, we show that the pregnancy-related hormone progesterone controls matrix components that influence CD83 availability during pregnancy. On the other hand, during inflammatory pregnancies, splenic but not peripheral B cells upregulate CD83 expression. Moreover, despite the higher mCD83 on splenic B cells, lower sCD83 is detected in the sera of affected mice. Our data suggest that tissue-specific components influence sCD83 availability during normal and impaired pregnancy.

\section{Material and methods}

\section{Animals}

$\mathrm{CBA} / \mathrm{J}\left(\mathrm{H} 2^{\mathrm{k}}\right)$ female and DBA/J $\left(\mathrm{H} 2^{\mathrm{d}}\right)$ male mice were purchased from Charles River or Janvier Labs (Saint-Berthevin Cedex, France). BALB/C $\left(\mathrm{H}^{\mathrm{d}}{ }^{\mathrm{d}}\right)$ males were bred in our Central Service and Research Facility for Animals (ZSFV). The animals were kept co-housed in a 12-h light/dark cycle with free access to food and water. Eight- to twelve-week-old CBA/J female mice were either paired with BALB/c males, generating normal pregnancies ('good pregnancy outcome mice' (GPOM)) or with DBA/2J males to obtain immune-induced pathological pregnancies ('poor pregnancy outcome mice' (PPOM)) (Clark et al. 1986, Muzzio et al. 2014b, 2016). In this mouse model, fetal resorptions are consequence of an immune rejection against paternal antigens (Clark et al. 1986), associated to a failure in regulatory $T$ cell (Treg) generation to compensate the pro-inflammatory cytokine boost driven by activated leukocytes (Clark et al. 2004). Mice were checked for vaginal plug every morning. Observation of a plug was declared as day 0 of pregnancy, and the female was separated from the male. Mice were killed at day 14 post plug ( $14 \mathrm{dpp}$ ); spleen, thymus, paraaortic and inguinal lymph nodes and blood were collected. Non-pregnant $\mathrm{CBA} / \mathrm{J}$ female mice were randomly killed and used for in vitro experiments. Animal experiments were carried out according to institutional guidelines approved by the Landesamt für Landwirtschaft, Lebensmittelsicherheit und Fischerei Mecklenburg-Vorpommern (LALLF-MV; 7221.3-1-068/13 to DM). The experiments were conducted in conformity with the European Communities Council Directive 86/609/EEC.

\section{Cell preparation}

Single-cell suspensions from para-aortic lymph nodes, inguinal lymph nodes, and thymus were obtained as previously described (Packhäuser et al. 2017). The tissue was carefully pressed through a 40- $\mu \mathrm{m}$ nylon cell strainer and washed with PBS. In case of spleen tissue, an erythrocyte lysis with $10 \mathrm{~mL}$ Lysis Buffer $\left(0.89 \% \mathrm{NH}_{4} \mathrm{Cl}, 0.1 \% \mathrm{KHCO}_{3}, 0.003 \%\right.$ EDTA) was performed and stopped after 5 min with $3 \mathrm{~mL}$ FBS. After washing, the cell suspension was filtered a second time with a $40-\mu \mathrm{m}$ cell strainer. The cell counts of the suspensions were determined using a Neubauer chamber.

\section{Flow cytometry}

Flow cytometry was applied to evaluate the expression of CD83 on B, T, or DCs from spleen, thymus, and lymph nodes as described before (Packhäuser et al. 2017). Cell suspensions were first incubated with CD16/32 mAb Fc block (BD Pharmingen, Heidelberg, Germany) for $5 \mathrm{~min}$. Staining with fluorochrome-labeled specific antibodies was performed for $30 \mathrm{~min}$ at $4^{\circ} \mathrm{C}$ in the dark. Samples from spleen were additionally stained with Fixable Viability Dye eFluor 780 (eBioscience) for $30 \mathrm{~min}$ and later washed with FACS buffer (1\% BSA (SigmaAldrich), $0.1 \% \mathrm{NaN}_{3}$ (Carl Roth, Karlsruhe, Germany) in DPBS) before Fc blocking. For intracellular staining, fixation and permeabilization of the cells were accomplished with BD Perm/Wash and BD Cytofix/Cytoperm (BD Biosciences) according to manufacturer's instructions. Subsequently, cells were incubated with fluorochrome-labeled antibodies for $30 \mathrm{~min}$ at $4^{\circ} \mathrm{C}$ for intracellular staining. Following antibodies were purchased from BD Bioscience CD83 (Michel-19); B220 (RA3-6B2); CD4 (RM4-4 and RM4-5); CD23 (B3B4); 
CD21 (7G6) and CD19 (1D3). Polyclonal goat IgG biotinylated anti-TIMP was purchased from R\&D. DC Marker DCIR2 (33D1) and Streptavidin were purchased from eBioscience. Data were acquired on FACSCanto (BD Bioscience) and analyzed by using Flowjo software (Flowjo, LLC).

\section{Cell stimulation}

$1 \times 10^{6}$ splenic lymphocytes or magnetic isolated splenic $\mathrm{CD}^{+}{ }^{+} \mathrm{B}$ cells (CD19 MicroBeads mouse; Miltenyi Biotec $\mathrm{GmbH}$ ) were cultured $48 \mathrm{~h}$ in a total volume of $500 \mu \mathrm{L}$ RPMI 1640 culture medium supplemented with 10\% FBS and antibiotics on 48-well flat-bottom suspension plates. The stimulation was performed with either $10 \mu \mathrm{g} / \mathrm{mL}$ LPS O111:B4 for $48 \mathrm{~h}$ and $50 \mathrm{ng} / \mathrm{mL}$ PMA as well as $500 \mathrm{ng} / \mathrm{mL}$ ionomycin (all from Sigma-Aldrich Chemie $\mathrm{GmbH}$ ) for the last $5 \mathrm{~h}$. In order to examine the influence of metalloproteinases on CD83 expression, cells were additionally stimulated with recombinant Mouse TIMP1 (100 ng/mL; BioLegend, San Diego, USA) or anti-TIMP1 $(1 \mu \mathrm{g} / \mathrm{mL}$; R\&D Systems $)$ from the beginning of the experiment for a total of $48 \mathrm{~h}$. In order to examine the influence of progesterone on CD83 expression, the cells were stimulated $50 \mathrm{ng} / \mathrm{mL}$ or $500 \mathrm{ng} /$ $\mathrm{mL}$ this pregnancy-related hormone (Sigma-Aldrich). After stimulation, cells and supernatants were separated by $5 \mathrm{~min}$ centrifugation at $300 \mathrm{~g}$ and the cells were directly used for flow cytometry or by $10 \mathrm{~min}$ at $8000 \mathrm{~g}$ to store the supernatants at $-80^{\circ} \mathrm{C}$ and lyse cells with peqGOLD TriFast ${ }^{\mathrm{TM}}$ (VWR, Radnor PA, USA) for RNA extraction.

\section{ELISA}

The levels of sCD83 in sera and supernatants were measured using an ELISA kit for CD83 (Cloud-Clone Corp., Houston, TX, USA). The serum samples were diluted 1:2 in PBS, while the supernatants were examined without dilution. The test was performed following the instruction manual.

\section{Real-time PCR}

Magnetic isolated splenic CD19+ $\mathrm{B}$ cells were treated with TriFast peqGOLD (VWR, Radnor PA, USA). RNA concentration was spectrophotometrically assessed in a the NanoPhotometer PEARL (IMPLEN, Munich, Germany). RNA was reversetranscribed applying High-Capacity cDNA Archive Kit (Applied Biosystems). For the GPCR, the samples were amplified in duplicate and non-template controls were included. Primer pairs were chosen to span an exon-exon junction to avoiding genomic DNA amplification. Real-time PCR was performed using Power SYBR® Green (AB/Life Technologies) in a 7300 Real-time PCR System (Applied Biosystems) with $A c t b$ as housekeeping gene. Primer sequences were the following: Cd83 forward: TGAAGGTGACAGGATGCCC; Cd83 reverse: CTTGGGGAGGTGACTGGAAG; Actb forward: TGGAATCCTGTGGCATCCATGAAAC; Actb reverse: TAAAACGCAGCTCAGTAACAGTCC. All primers were purchased from Invitrogen.

\section{Statistical analysis}

In vivo and ex vivo data comparing GPOM vs PPOM pregnancies were analyzed by unpaired Student's $t$-test. In vitro data comparing treatments and control were analyzed by paired Student's $t$-test or repeated-measures ANOVA with Dunnett's posttest where applicable.

\section{Results \\ $m C D 83$ is upregulated in PPOM in a cell- and compartment-dependent manner}

We observed higher mCD83 expression on splenic B cells in PPOM as compared to GPOM (2.26 \pm 0.27 -fold increase; $P<0.001$; Fig. 1B). This was accompanied by higher percentages of $\mathrm{mCD} 3^{+} \mathrm{B}$ cells $(1.74 \pm 0.19$ in GPOM vs $2.54 \pm 0.22$ in PPOM; $P<0.05$; Fig. 1C). Although an increment in the percentage of $\mathrm{CD}^{2} 3^{+}$cells could be observed within splenic DCs $(8.31 \pm 1.06$ in GPOM vs $20.7 \pm 2.62 \%$ in PPOM; $P<0.001$; Fig. 1C) and T cells $(0.11 \pm 0.01$ in GPOM vs $0.19 \pm 0.03 \%$ in PPOM; $P<0.05$; Fig. $1 \mathrm{C}$ ), the overall mCD83 expression level was not significantly different. We also analyzed the expression of the main mature splenic $B$ cell subsets, $C D 21 / 35^{\text {hi }} C D 23^{\text {low }}$ marginal zone $(M Z)$ and $C D 21 / 35^{\text {int }} C D 23{ }^{\text {hi }}$ follicular zone (FO) B cells. Both, FO and MZ B cells expressed significantly higher levels of mCD83 in PPOM than in GPOM mice $(2.05 \pm 0.24$-fold increase in $\mathrm{FO}$ and $3.52 \pm 0.75$-fold increase in $M Z B$ cells respectively; $P<0.001$; Fig. 1B). Within B cell subpopulations, $\mathrm{mCD}^{+} 3^{+}$percentages were significantly increased only in $M Z B$ cells $(1.60 \pm 0.15$ in GPOM vs $2.57 \pm 0.21 \%$ in PPOM; $P<0.01)$.

In contrast, no significant differences were found in the mCD83 expression on peripheral B cells of thymus and uterus-draining lymph nodes (Fig. 1B). In thymus, however, we observed that mCD83 was elevated in DCs as well in $\mathrm{CD}^{+} \mathrm{T}$ cells of PPOM mice as compared to GPOM $(2.32 \pm 0.18$-fold increase in DC and 1.18 \pm 0.02 -fold increase in T cells; $P<0.001$ and $P<0.01$ respectively; Fig. $1 \mathrm{~B})$. The percentage of $\mathrm{mCD} 3^{+}$cells was, however, reduced in thymic $\mathrm{CD}^{+} \mathrm{T}$ cells $(0.66 \pm 0.08$ in GPOM vs $0.44 \pm 0.04 \%$ in PPOM; $P<0.05$; Fig. 1C). Both uterine-draining lymph nodes (inguinal (ILN) and paraaortic (PLN)) showed higher mCD83 expression on DCs in PPOM as compared to GPOM $(2.07 \pm 0.17$ and $2.29 \pm 0.23$-fold increase respectively; $P<0.001$; Fig. $1 \mathrm{~B})$.

In summary, mCD83 was upregulated on different lymphocyte subpopulations of PPOM. There was a significant difference in the expression of mCD83 molecule in splenic B cells and dendritic cells from thymus and uterus-draining lymph nodes. 
A
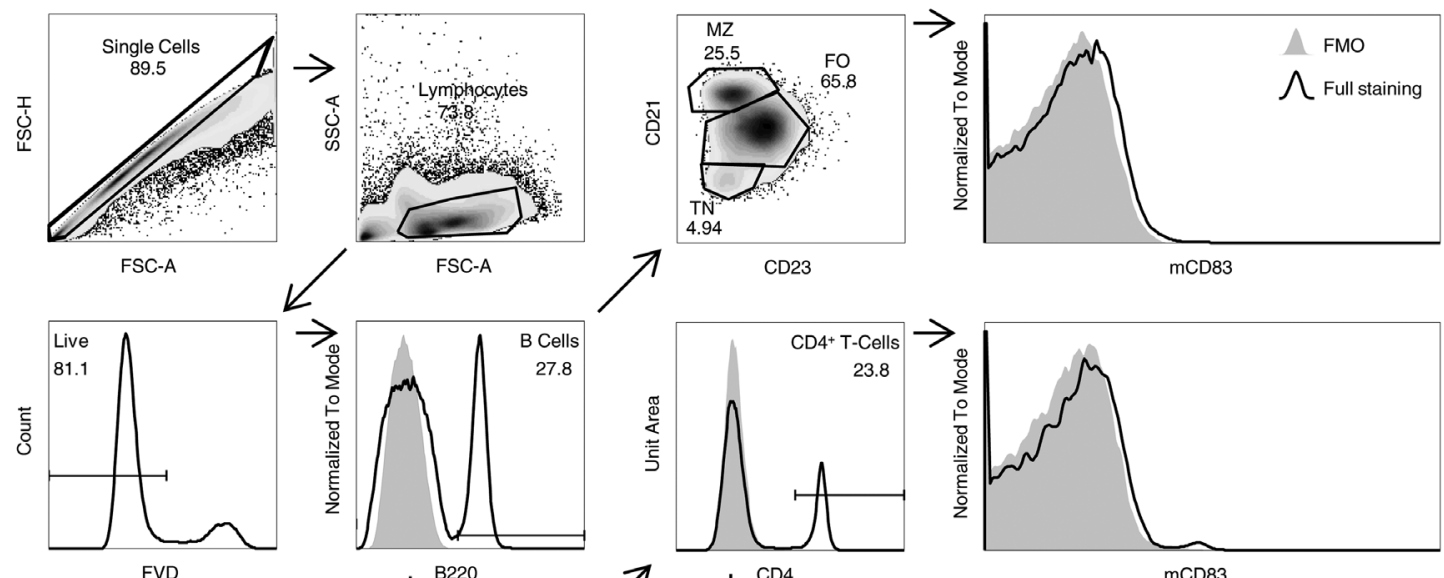

G GPOM

- PPOM
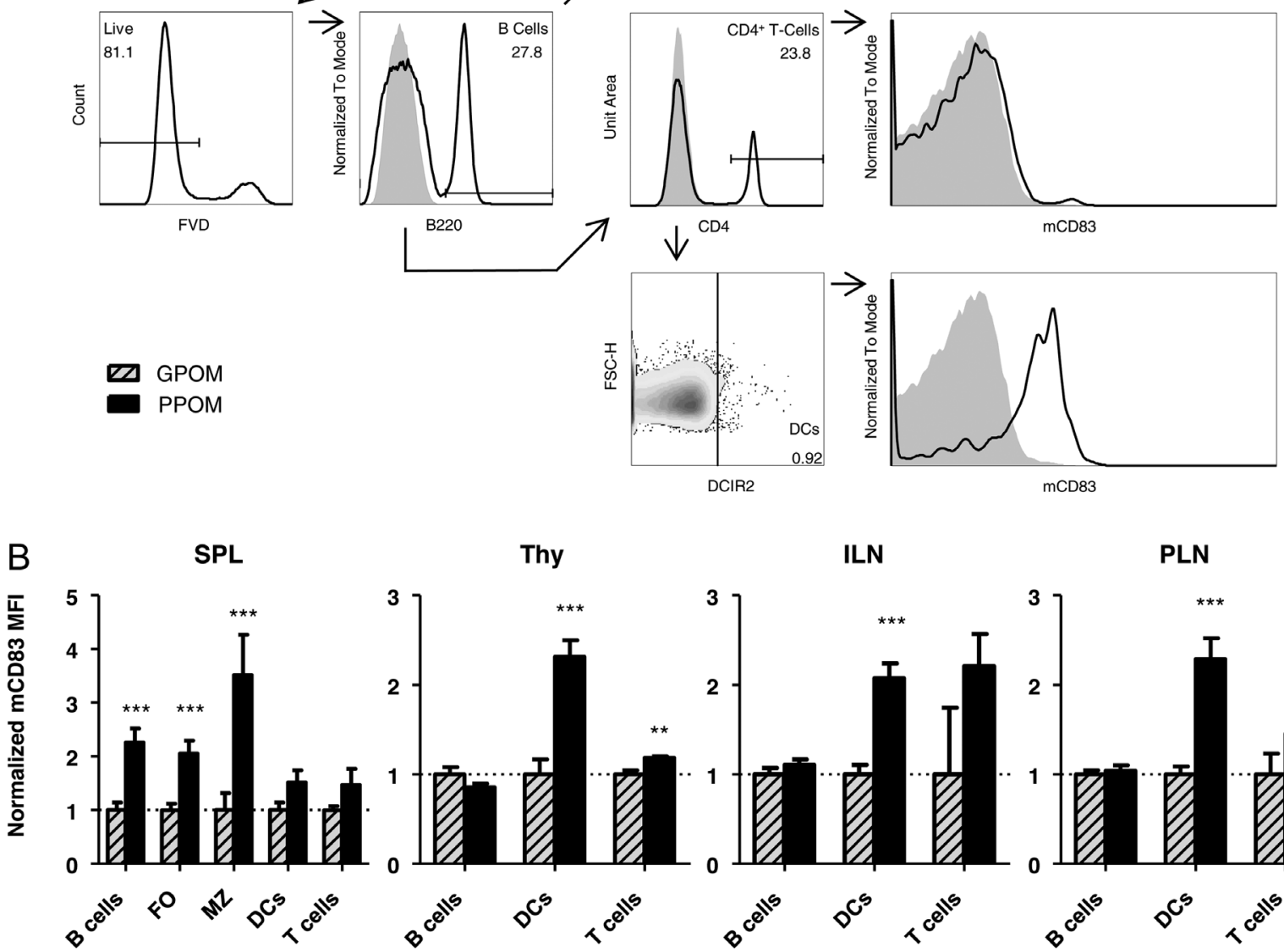

Thy

ILN

PLN
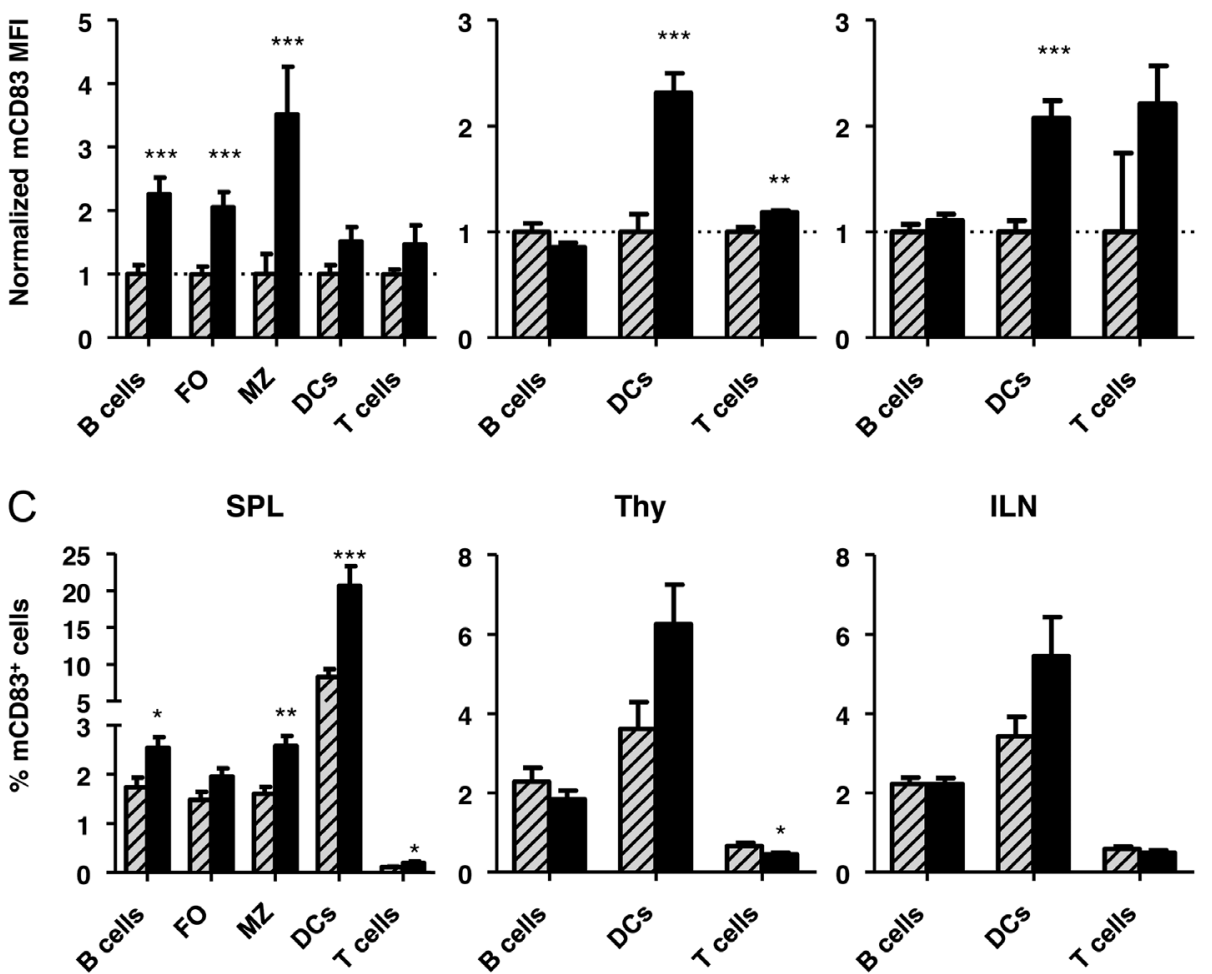

ILN

PLN

Thy
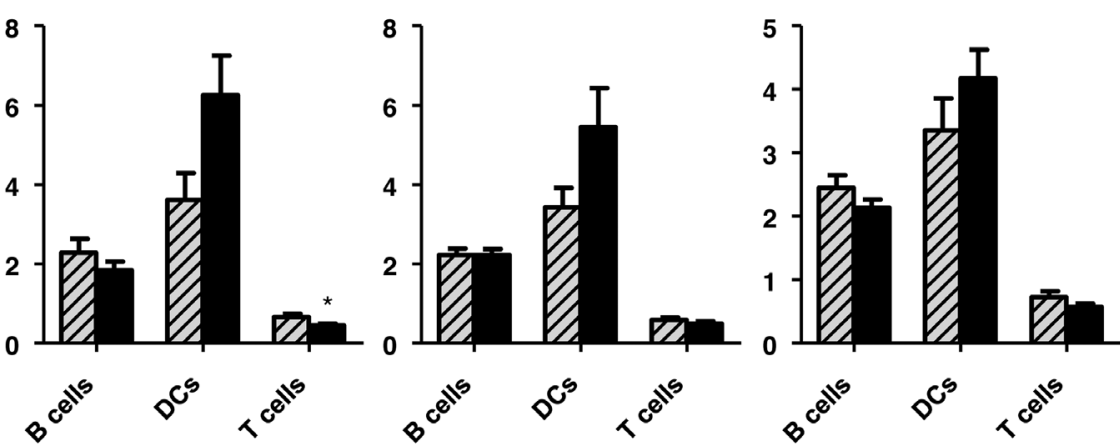

Figure 1 PPOM express higher mCD83 than GPOM in splenic but not in peripheral B cells in vivo. B cells $\left(\mathrm{B} 220^{+}\right)$, $\mathrm{T}_{\text {cells }}\left(\mathrm{CD} 4^{+}\right)$and dendritic cells (DCIR2+) from GPOM $(n=16)$ were compared to cells from PPOM $(n=22)$. (A) Representative plots show gating strategies for determination of mCD83 expression. In overlapping histograms (right), the gray area represents the unstained control and the black line the positive staining. Bars show the relative median fluorescence intensity (MFI) of mCD83 (B) or the percentage of $\mathrm{mCD} 83^{+}$cells $(\mathrm{C})$ in live B cells $\left(\mathrm{B} 220^{+}\right)$, T cells $\left(\mathrm{CD}^{+}\right)$and dendritic cells $\left(\mathrm{DCIR} 2^{+}\right)$from spleen (SPL), thymus (THY), paraaortic (PLN) and inguinal (ILN) lymph nodes. In spleen, B220 ${ }^{+}$B cells were further subdivided in $C D 21 / 35^{\text {hi }} C D 23^{\text {low }}$ marginal zone B cells $(M Z)$ and $C D 21 / 35^{\text {int }} C D 23^{\text {hi }}$ follicular zone B cells (FO). All data were analyzed using Student's $t$-test $(n \geq 16)$. Significant differences are indicated $\left({ }^{*} P \leq 0.05,{ }^{* *} P \leq 0.01,{ }^{* * *} P \leq 0.001\right)$. 


\section{Ex vivo stimulation reveals no difference between PPOM and GPOM expression of $m C D 83$ and $s C D 83$}

Taking into account the discrepancy in terms of mCD83 expression between splenic and peripheral B cells, we moved forward to compare splenic B cell expression of mCD83 after ex vivo stimulation with inflammatory signals. Here, neither differences in the mCD83 expression nor in the sCD83 release could be depicted between the two groups of mice after 48 -h stimulation (Fig. 2A and B).

\section{A pregnancy-specific hormone influences sCD83 expression}

In our previous work, we found splenic B cells to be a major source of sCD83 during pregnancy and we suggested that it may contribute to anti-inflammatory responses that support pregnancy maintenance (Packhäuser et al. 2017). In this experiment, we found that GPOM had higher serum levels of sCD83 than pro-inflammatory PPOM at day 14 of pregnancy $(2308.65 \pm 176.92 \quad$ vs $1638.89 \pm 76.3048 \mathrm{pg} / \mathrm{mL}$ respectively, Fig. $3 \mathrm{~A}$ ).

During pregnancy a variety of immune and nonimmune adaptations take place regulated that is by the sexual hormones estradiol and progesterone. In our previous work, we found progesterone but not estradiol regulating mCD83 on splenic B cells, T cells and DCs.

Here, splenic lymphocytes or magnetically isolated CD19+ splenic B cells from non-pregnant CBA/J female mice were stimulated with $500 \mathrm{ng} / \mathrm{mL}$ progesterone (the same order of magnitude as during murine pregnancies; Hashimoto et al. 2010). The treatment led to a significant reduction of $\mathrm{sCD} 83$ in the supernatants of the cell culture of splenocytes $(374.40 \pm 20.60$ vs $303.69 \pm 16.07 \mathrm{pg} / \mathrm{mL}$ ) and $B$ cells $(590.63 \pm 26.55$ vs $508.95 \pm 10.16 \mathrm{pg} / \mathrm{mL})$ compared to the respective controls; $P<0.05$; Fig. $3 \mathrm{~B}$.
To determine if the effect of progesterone was linked to a reduced production of CD83, we stimulated splenic lymphocytes with progesterone and/or LPS. We did not observe any significant changes in the levels of intracellular staining for CD83 (iCD83), although a significant reduction at the mRNA levels could be seen (from $1.472 \pm 0.59$ to $1.303 \pm 0.52$ after progesterone treatment; Fig. 3C).

The effect of progesterone on CD83 expression on resting lymphocytes was also assessed performing intra and extracellular staining of CD83. Progesterone treatment led to a reduction on both, mCD83 $(216.75 \pm 6.09 \mathrm{MFI}$ for untreated controls, $199.67 \pm 4.20$ for $50 \mathrm{ng} / \mathrm{mL}$ progesterone and $183.84 \pm 5.00$ with $500 \mathrm{ng} / \mathrm{mL}$, Fig. 3D) and iCD83 (241.8 $\pm 32.86 \mathrm{MFI}$ for untreated controls, $229.6 \pm 34.94$ with $500 \mathrm{ng} / \mathrm{mL}$ progesterone, $P<0.05, n=7$, data not shown). The effect of progesterone on $\mathrm{mCD} 83$ was stronger than on iCD83 $(0.849 \pm 0.016$ vs $0.937 \pm 0.025)$. At the mRNA levels, progesterone did not have any significant effect on Cd83 expression (Fig. 3D).

\section{TIMP1 increases sCD83 availability ex vivo}

Since the reduction of sCD83 in the supernatants of progesterone-treated B lymphocytes correlated with a reduction of $\mathrm{mCD} 83$ levels, we looked for mechanisms that would affect CD83 membrane turnover, decreasing mCD83 and sCD83 availability. Many membrane proteins are target of degradation by proteinases which are regulated by proteases inhibitors. The metallopeptidase inhibitor 1 (TIMP1) is expressed on B cells (Alter et al. 2003) and a known target of progesterone as well (Imada et al. 1994, Hampton et al. 1999). Using isolated lymphocytes, we were able to show that progesterone led to significantly decreased TIMP1 expression on splenic B cells $(378.17 \pm 12.97$ after progesterone treatment vs
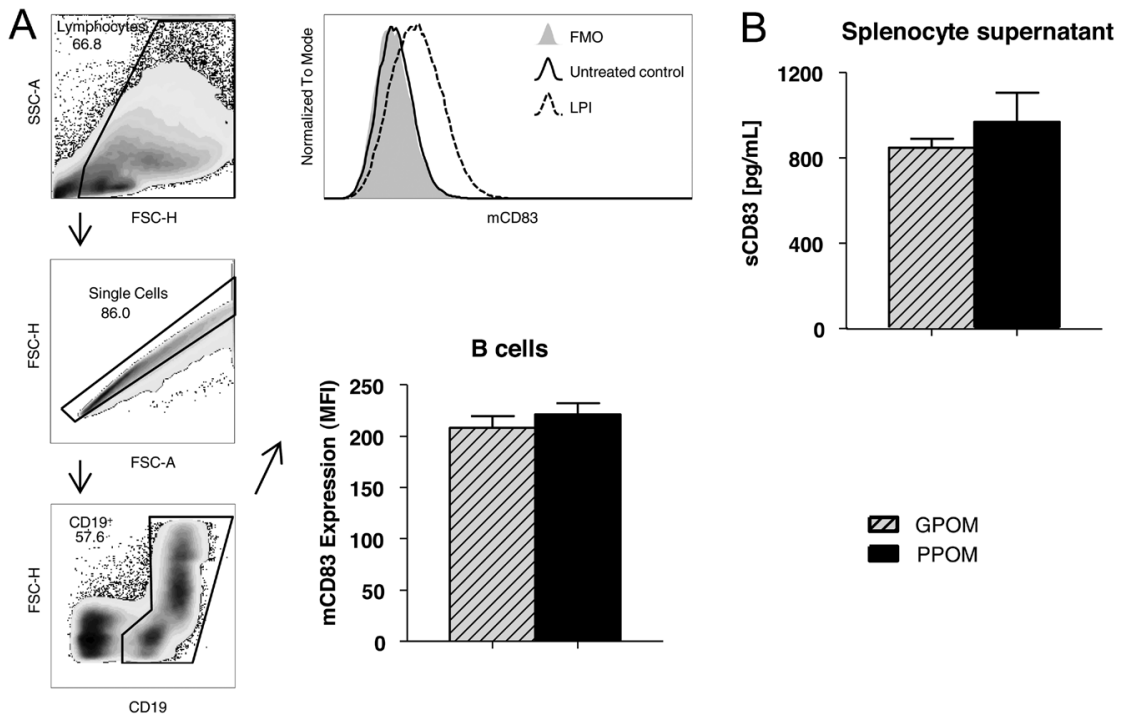

https://rep.bioscientifica.com
Figure 2 Ex vivo stimulation of splenic B cells reveals no difference in $\mathrm{mCD} 83$ expression between GPOM and PPOM. (A) Splenic lymphocytes were stimulated with LPS for $48 \mathrm{~h}$ with PMA and ionomycin for the last $5 \mathrm{~h}$ (LPI). Plots show a representative gating strategy for determination of $\mathrm{mCD} 83$ expression on CD19+ B cells (left). The overlapping histograms display mCD83 expression of untreated (filled line) and LPI-stimulated B cells (dashed line). Gray area represents the FMO for CD83. Bars show the corresponding median fluorescence intensities (MFI) of mCD83 (bottom-right) on LPI-stimulated B cells. (B) Supernatants of the LPI-stimulated lymphocytes were analyzed by ELISA to determine sCD83 levels. All data were analyzed using Student's $t$-test (A: $n=10$, B: $n=9)$. 

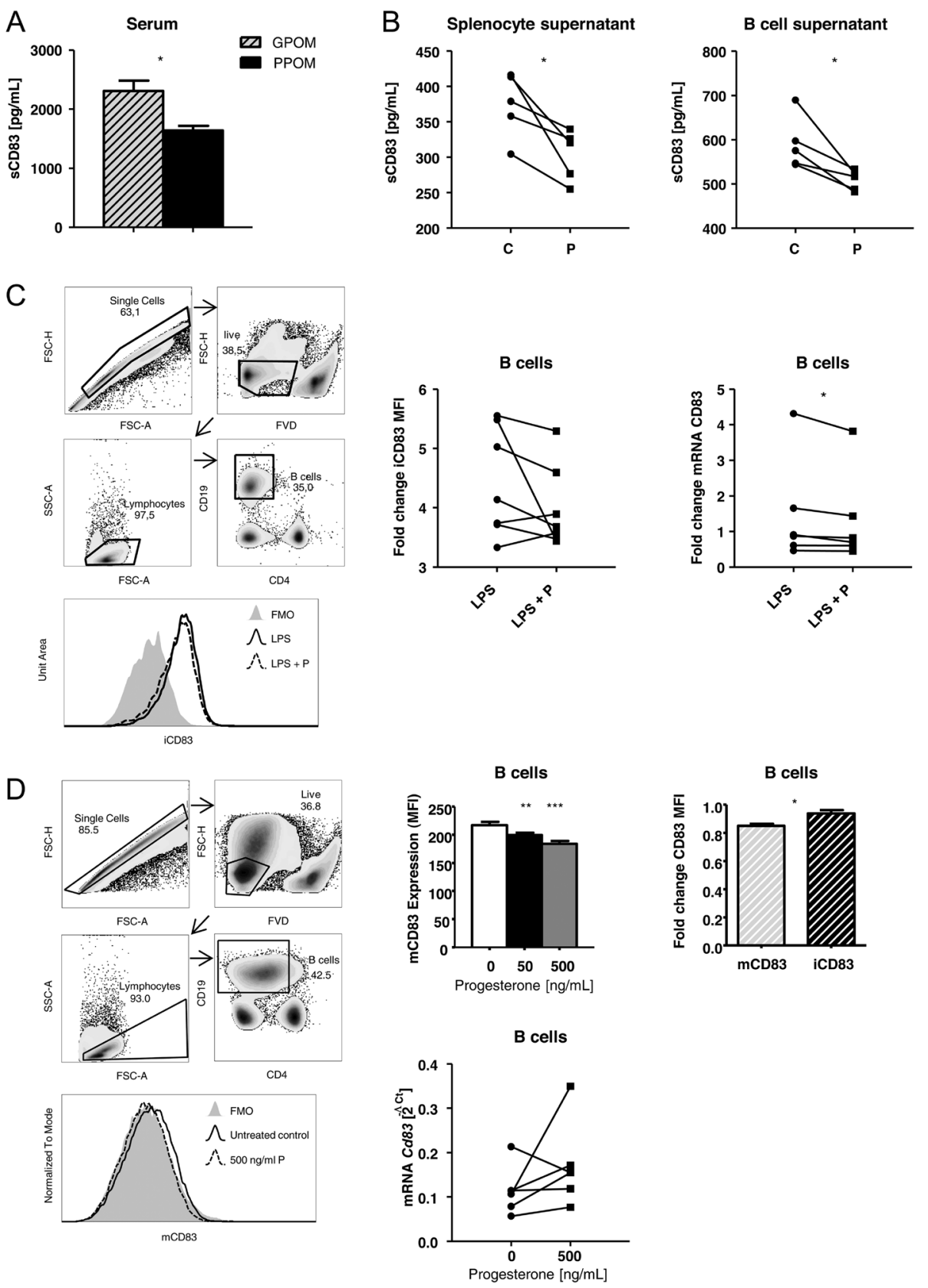

Figure 3 Progesterone reduces mCD83 and sCD83 availability in vitro. (A) Sera of pregnant mice were analyzed by ELISA to determine sCD83 levels. Data were analyzed using Student's $t$-test (GPOM $n=19$, PPOM $n=8)$. Significant differences are indicated $\left({ }^{*} P \leq 0.05\right)$. (B) Splenic lymphocytes or magnetically isolated CD19+ B cells from the spleen of non-pregnant CBA/J mice were cultured for $48 \mathrm{~h}$ with progesterone or with medium alone as control. Graph shows levels of SCD83 of supernatants determined by ELISA. Data were analyzed using paired $t$-test $(n=5)$. Significant differences are indicated $\left({ }^{*} P \leq 0.05\right)$. (C) Splenic lymphocytes from non-pregnant CBA/J mice were cultured for $48 \mathrm{~h}$ with LPS alone or with LPS and $500 \mathrm{ng} / \mathrm{mL}$ progesterone. PMA and ionomycin were added for the last $5 \mathrm{~h}$. The plots show a representative gating strategy (left). Overlapping histograms (right) display differences in iCD83 between LPS (filled line) and LPS with progesterone (dashed line) stimulated CD19+ B cells. Gray area represents the FMO for CD83. Data represent the fold increase of iCD83 MFI (middle) or Cd83 mRNA (right) in splenic CD19+ B cells over the corresponding untreated controls. Data were analyzed using paired $t$-test (flow cytometry: $n=7 ; q P C R: n=6$ ). (D) Splenic lymphocytes from non-pregnant CBA/J mice were cultured for $48 \mathrm{~h}$ with or without the presence of $50 \mathrm{or} 500 \mathrm{ng} / \mathrm{mL} \mathrm{progesterone}$. The plots show a representative gating strategy (left). Overlapping histogram displays differences between with progesterone-stimulated B cells (dashed line) and untreated control (filled line). Gray area represents the FMO for CD83. Bars (top-middle) show the corresponding median fluorescence intensity (MFI) of mCD83 within CD19+ B cells (right-bottom). Bars (right) display the fold change of either mCD83 ( $n=4)$ or iCD83 ( $n=7) \mathrm{MFI}$ after progesterone treatment. Graph (bottom) shows Cd83 mRNA levels of control vs progesterone-treated B cells $(n=6)$. Data from flow cytometry were analyzed by ANOVA and Dunnett's Multiple Comparison test to compare treatments against control (top-middle) or unparited $t$-test (right). Data from qPCR were analyzed by paired $t$-test $(n=6)$. Significant differences are indicated $(* * P \leq 0.01, * * * P \leq 0.001)$. 
A
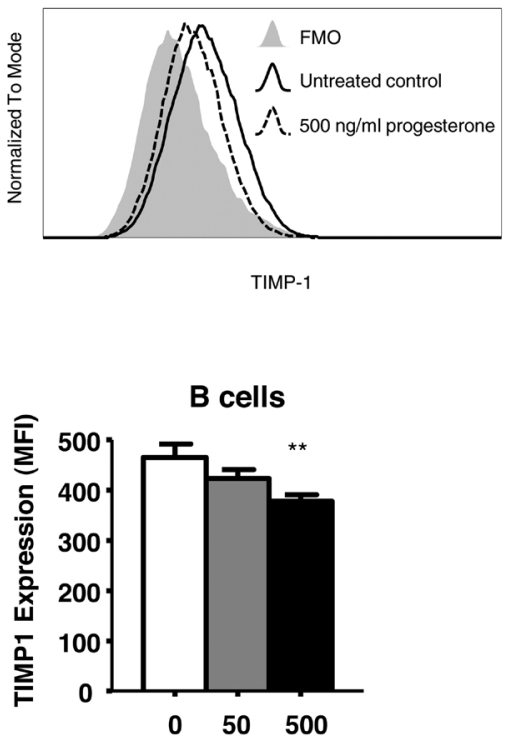

Progesterone $[\mathrm{ng} / \mathrm{mL}]$

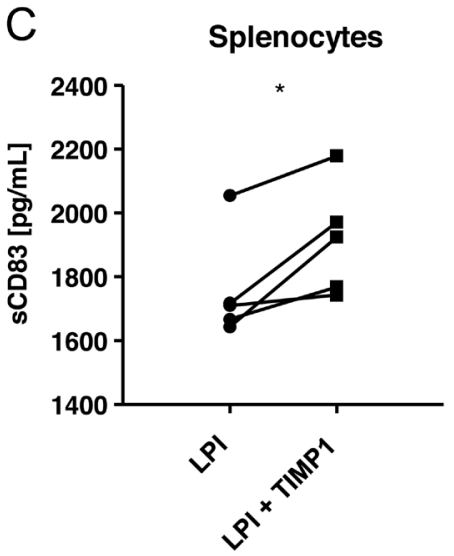

B
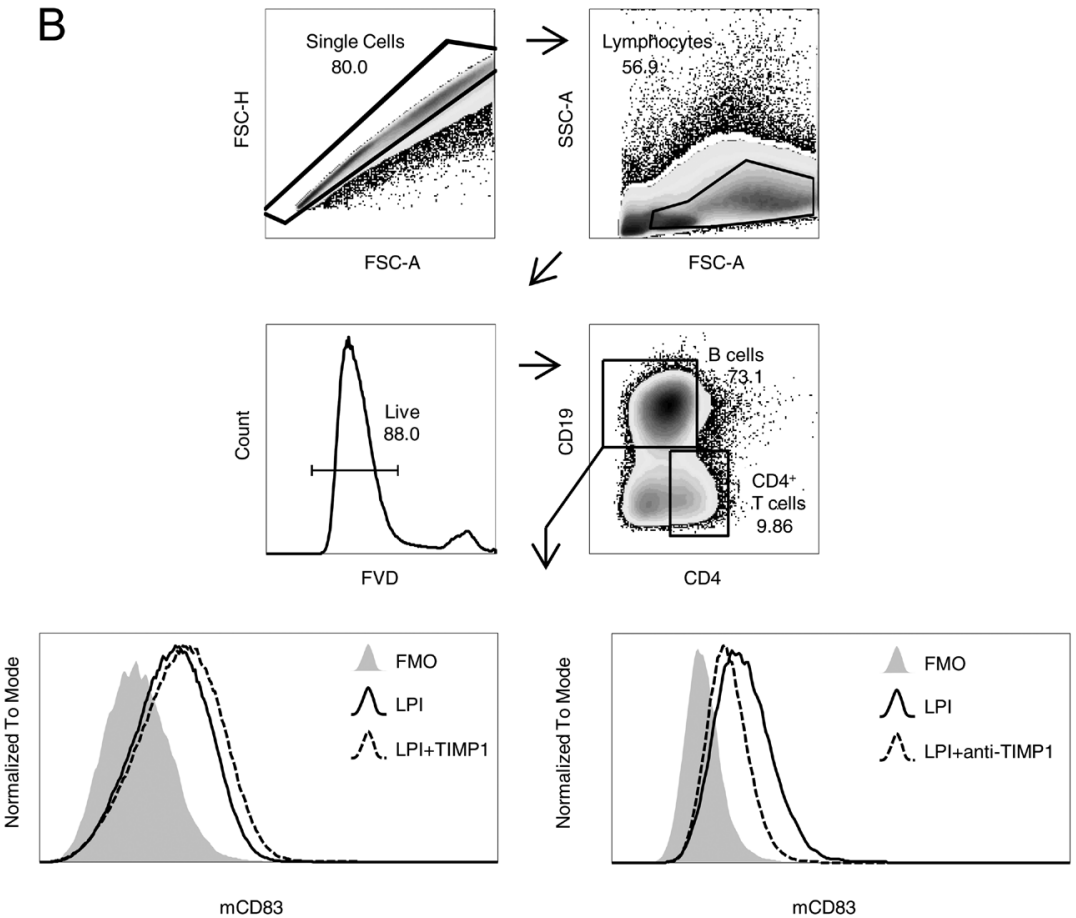

$\downarrow$
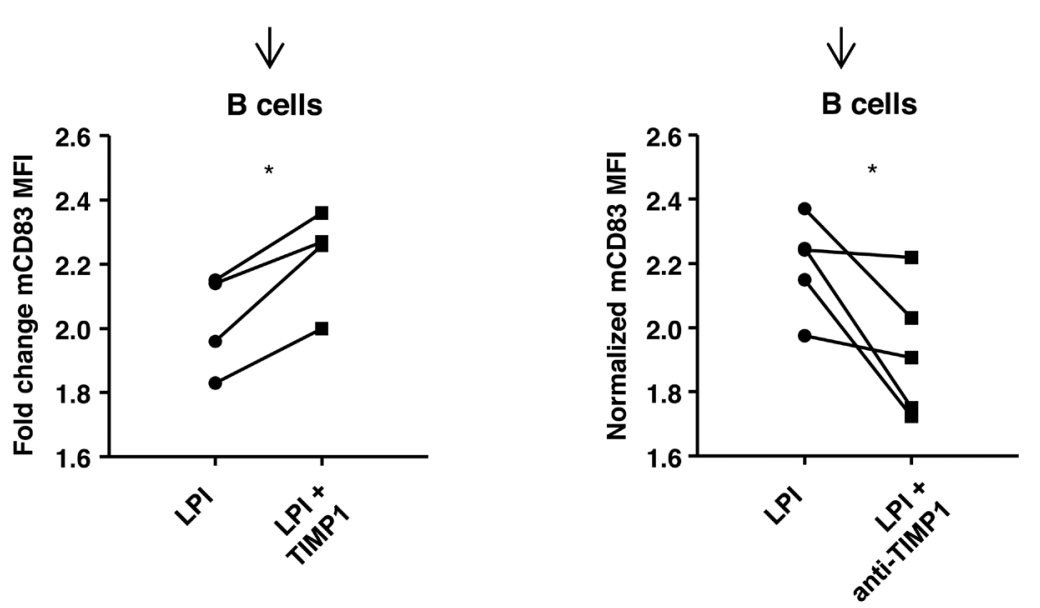

Figure 4 The metallopeptidase inhibitor TIMP1 increases mCD83 and sCD83 availability in vitro. (A) Splenic lymphocytes from non-pregnant CBA/J mice were cultured for $48 \mathrm{~h}$ with 50 or $500 \mathrm{ng} / \mathrm{mL}$ progesterone. Cells cultured in medium alone served as control. Overlapping histograms (top) display differences between progesterone-stimulated B cells (dashed line) and untreated control (filled line). Gray area represents the FMO for TIMP1. Bars show the median fluorescence intensity (MFI) of TIMP1 within CD19+ B cells (bottom). Data were analyzed by ANOVA and Dunnett's multiple comparison test to compare treatments with controls $(n=4)$. Significant differences are indicated $(* * P \leq 0.01)$. (B) Splenic lymphocytes were cultured for $48 \mathrm{~h}$ with LPS and for the last $5 \mathrm{~h}$ with PMA and ionomycin (LPI). Recombinant TIMP1 or anti-TIMP1 blocking antibody were added from the beginning of the experiment. Scatter dot plots show a representative gating strategy to CD19+ B cells and $\mathrm{CD}^{+}{ }^{+} \mathrm{T}$ cells (top). Overlapping histograms display differences between TIMP1 (middle-left) or anti-TIMP1 (middle-right) expression on CD19+ B cells (dashed lines) and the respective controls (filled line). Gray curve represents the FMO for mCD83. The bottom-left graph shows the fold increase of the corresponding MFI of mCD83 on CD19+ B cells after stimulation with LPI and TIMP1 $(n=4)$. The bottom-right graph represents the normalized MFI of mCD83 on CD19+ B cells after stimulation with LPI and anti-TIMP1 $(n=5)$. Data were analyzed using paired $t$-test. Significant differences are indicated $\left({ }^{*} P \leq 0.05\right)$. (C) Graph shows the amount of SCD83 in supernatants of LPI or LPI and TIMP1-treated splenocytes determined by ELISA. Data were analyzed using paired $t$-test $(n=5)$. Significant differences are indicated $(* P \leq 0.05)$.

465.92 $\pm 26.59 \mathrm{MFI}$ in controls, respectively; $P<0.01$; Fig. 4A), supporting the idea of a protease involvement regulating CD83 availability.

To confirm that TIMP1 was involved in the changes of $\mathrm{m}$ - and $\mathrm{sCD} 83$ expression, we cultured splenic lymphocytes with LPS and either recombinant TIMP1 or a blocking antibody against TIMP1. TIMP1 treatment was able to elevate mCD83 expression $(2.02 \pm 0.08$ in $\mathrm{LPI}$ vs $2.22 \pm 0.08$-fold increase with LPI and TIMP1, respectively; $P<0.05$, Fig. 4B), while anti-TIMP1 reduced 
it $(2.197 \pm 0.07$ in LPI vs $1.926 \pm 0.09$-fold increase with LPI and Anti-TIMP1, respectively; $P<0.05$; Fig. 4B). Furthermore, TIMP1 treatment of splenocytes led to significantly increased sCD83 release $(1917.66 \pm 78.81$ with LPS and TIMP1 vs $1758.61 \pm 75.40 \mathrm{pg} / \mathrm{mL}$ for LPS-treated controls; $P<0.05$; Fig. 4C).

In summary, TIMP1 effects on mCD83 inversely correlate with those observed with progesterone, favoring sCD83 availability.

\section{Discussion}

$\mathrm{CBA} / \mathrm{J} \times \mathrm{DBA} / 2 \mathrm{~J}$ pregnancies (here referred as $\mathrm{PPOM}$ ) are characterized by a failed maternal tolerance (Clark et al. 1980). The pro-inflammatory manifestations can be observed systemically in the mother and locally at the resorptive fetoplacental unit (Ahmed et al. 2010). Innate cells, including neutrophils, NK cells, macrophages and DCs have been found to be the main effectors of the resorptive phenotype (Bonney \& Brown 2014).

mCD83 was first described as a maturation marker for DCs and its expression on DCs is linked to a higher pro-inflammatory potential (Aerts-Toegaert et al. 2007, Wilson et al. 2009, Pinho et al. 2014, Seldon et al. 2016). $\mathrm{mCD} 83^{+} \mathrm{DCs}$ are present in human decidua and in high numbers associated with miscarriage (Askelund et al. 2004, Qian et al. 2015). Our data show that DCs from the uterus-draining lymph nodes in PPOM expressed higher levels of mCD83 than in GPOM, which supports the observations in human studies.

$\mathrm{CD}^{+} \mathrm{T}$ cells can as well express $\mathrm{mCD} 83$, for which both anti- and pro-inflammatory roles were suggested, depending on the subpopulation of $\mathrm{T}$ cell that was studied (Wolenski et al. 2003, Reinwald et al. 2008). Although we did not analyze different $\mathrm{CD}^{+} \mathrm{T}$ cell subsets in detail, we observed the significant differences between both groups of mating only in thymic T cells. As PPOM expressed higher levels of mCD83 than GPOM, we assume that mCD83 expression on thymic CD4 ${ }^{+}$ $\mathrm{T}$ cells is accompanying the pro-inflammatory $\mathrm{T}$ cell repertoire that was already described in those mice.

Similarly, B cells in spleen depicted significant differences in mCD83 expression. In our previous work, we showed that healthy murine pregnancy is accompanied by an upregulation of $\mathrm{mCD} 83$ expression on splenic B cells in vivo. Moreover, splenic B cells from pregnant mice acquire a higher capacity to upregulate mCD83 expression after stimulation with proinflammatory signals as LPS (Packhäuser et al. 2017). PPOM pregnancies are characterized by higher levels of pro-inflammatory cytokines, including TNFA and IFNG, which contribute to the disturbed pregnancy phenotype (Clark et al. 1998). These cytokines are as well inducers of mCD83 expression (Li et al. 2012, Lin et al. 2018). As expected for pro-inflammatory pregnancies, splenic $\mathrm{B}$ cells from PPOM displayed higher levels of mCD83 than in GPOM.
The fact that differences in $\mathrm{mCD} 83$ expression on B cells are absent in uterus-draining lymph nodes suggests that there may be mechanisms to limit CD83 expression in the periphery even during pro-inflammatory pregnancies. Our results suggest that compartmentation and matrix components seem to play a role regulating the CD83 biology. In fact, B cells in spleen are compartmentalized and they migrate upon activation (Pereira et al. 2010). In the splenic stroma, B cells interact with several cell types that exert a considerable influence on the B cell fate (Mueller \& Germain 2009). We observed that PPOM, despite their higher mCD83 expression on different lymphocyte population, displayed lower serum levels of sCD83. It has been suggested that proteolytic shedding may lead to the release of sCD83 from its membrane-bound form (Hock et al. 2001). Then, a higher splenic mCD83 expression accompanied with lower sCD83 release suggests that if a protease is involved, its function diminished in PPOM (Fig. 5).

Consistent with this, we observed that in ex vivo stimulated splenic B cells, progesterone limits CD83 availability in a process which seems to be mediated by TIMP1. TIMP1 influenced CD83 availability, increasing mCD83 expression and sCD83 release after ex vivo stimulation of splenic B cells. Progesterone treatment, on the other hand, induced TIMP1 downregulation, reducing CD83 availability (Fig. 6).
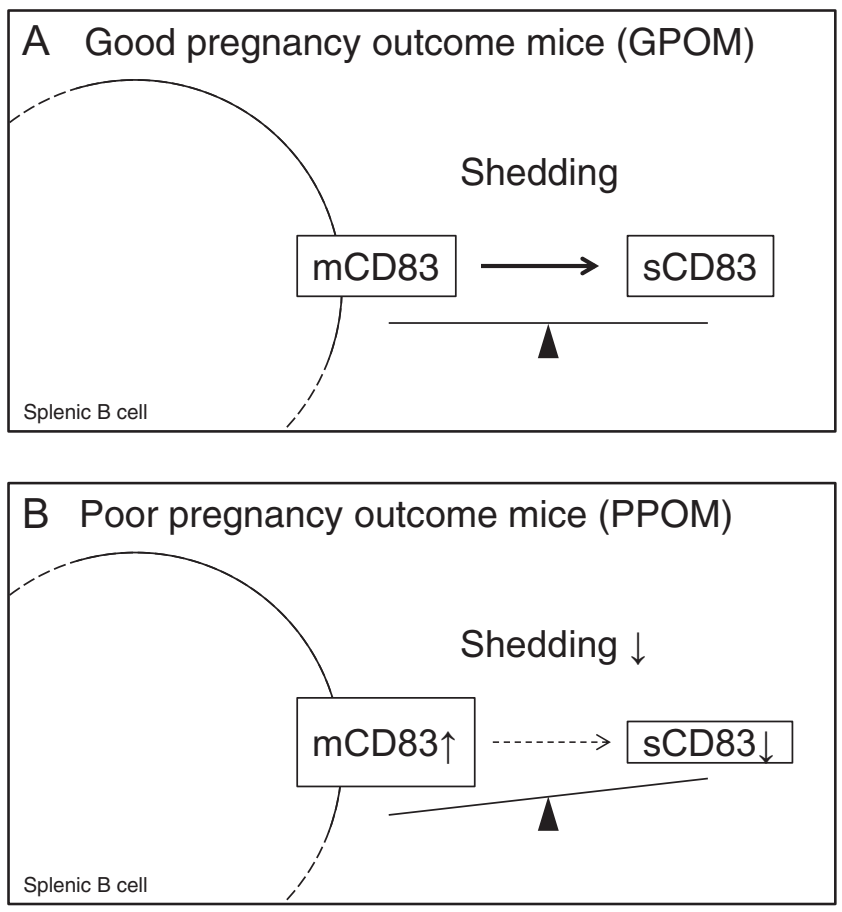

Figure 5 Schematic summary of CD83 shedding in GPOM and PPOM on splenic B cells. In GPOM (A), a balanced shedding of $\mathrm{mCD} 83$ provides the source of sCD83 in healthy pregnancies. In contrast, an imbalanced shedding of $\mathrm{mCD} 83$ in PPOM (B) results in reduced $\mathrm{sCD} 83$ release. 

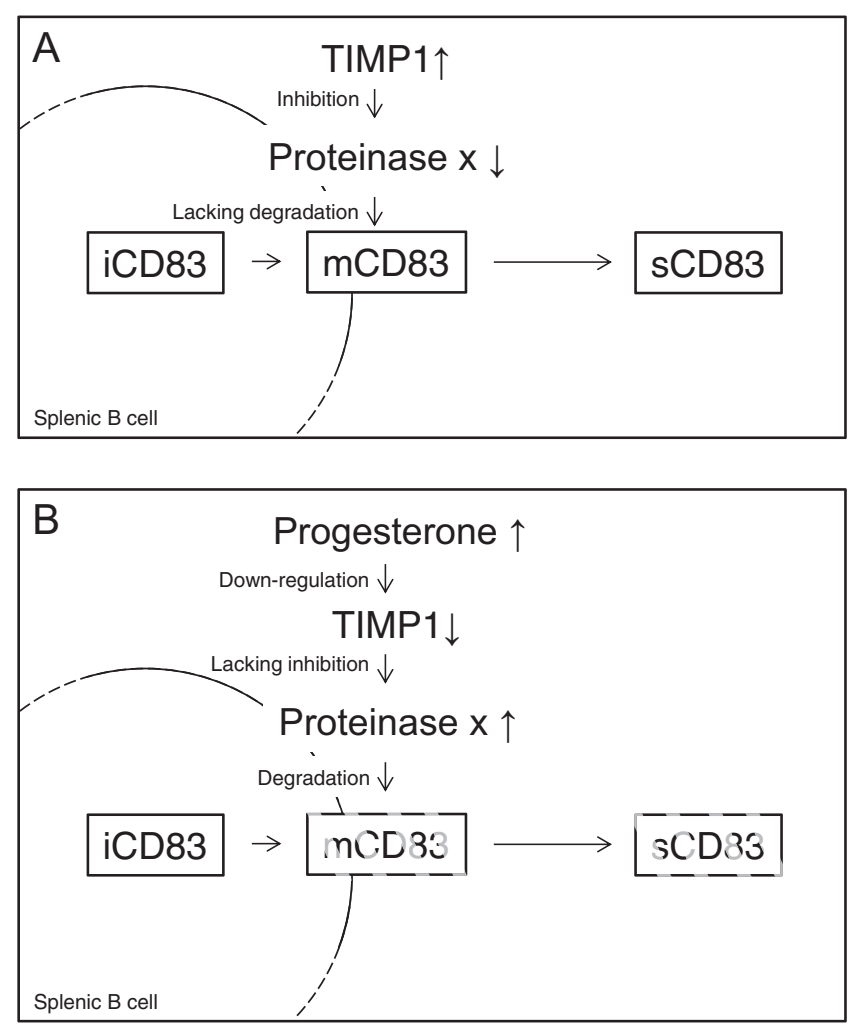

Figure 6 Schematic summary of the proposed progesteronedependent regulation of CD83 availability by TIMP1. (A) TIMP1 inhibition of a proteinase that degrades mCD83 results in a higher mCD83 expression and therefore improved availability for sCD83 release. (B) Progesterone, acting through inhibition of B cell TIMP1 expression, facilitates the degradation of $\mathrm{mCD} 83$, reducing $\mathrm{mCD} 83$ expression and SCD83 release.

Progesterone may display contradictory roles depending on the target cell. In the case of TIMP1 production, for example, progesterone showed a negative effect on B lymphocytes but induces TIMP1 expression in uterine fibroblasts (Imada et al. 1994) and human endometrial stromal cells (Hampton et al. 1999). Then, if the influence of stromal-derived TIMP1 or metalloproteinases prevails over the local effect on B cell expressed TIMP1, we may observe the contrary phenotype in splenic B cells in vivo than in ex vivotreated cells. So the effect that we observed on isolated lymphocytes may correspond to a peripheral/activated phenotype, as in the case of a local inflammatory process. In this case, activated B cells could leave their niches and act to contribute to a pro-inflammatory response during pregnancy minimizing the anti-inflammatory effect of sCD83 release.

In this scenario, progesterone would exert a regulatory role on sCD83 availability in B cells that had left the splenic compartment, which find no impediment in acting in a pro-inflammatory manner. Splenic B cell residents, on the other hand, remain as source of systemic sCD83 that may contribute to pregnancy maintenance.
As proposed for sCD83, certain soluble factors as TNFA, TGFA and TACl are derived by cleavage from their latent or the extracellular domains of their respective membrane proteins in a process that is mediated by metalloproteinases from the ADAM family (Murphy 2008, Hoffmann et al. 2015). These metalloproteinases can be produced by the same lymphocytes that express such factors or they can be released by cells of the stromal cells into the extracellular matrix. Metalloproteinases and their inhibitory molecules have critical roles during pregnancy, and their synthesis and release are under hormonal control. We found that while progesterone treatment reduces $\mathrm{sCD} 83$ release, ADAM10 expression is reduced and ADAM17 is unchanged in B cells (data not shown). Because this is associated to a reduced mCD83 expression and TIMP1 expression, it seems unlikely that these ADAM proteases are involved in the sCD83 release. The mechanisms of sCD83 release need further evaluation.

Overall, our data indicate that matrix components regulate $\mathrm{mCD} 83$ expression during pregnancy impacting on sCD83 availability. These components may be compromised in pro-inflammatory pregnancies, leading to altered sCD83 release.

\section{Declaration of interest}

The authors declare that there is no conflict of interest that could be perceived as prejudicing the impartiality of the research reported.

\section{Funding}

This study was supported by a grant from GANI_MED (FOMM-2015-10) to D M and intramural funding from Greifswald University.

\section{Author contribution statement}

$\mathrm{R}$ E and K P performed experiments, analyzed data and contributed to the elaboration of the manuscript. J E and A T performed experiments and analyzed data. M Z contributed with reagents, the design of experiments and the writing of the manuscript. D M conceived and designed the experiments, analyzed data, contributed with reagents, wrote the paper and supervised the work.

\section{Acknowledgements}

The authors thank the Gerhard Domagk Young Professional Development Program for their support to $\mathrm{K} \mathrm{P}$ and the Landesgraduiertenförderung Mecklenburg-Vorpommern (State Graduate Funding MV) of the University of Greifswald supporting R E. 


\section{References}

Aerts-Toegaert C, Heirman C, Tuyaerts S, Corthals J, Aerts JL, Bonehill A, Thielemans K \& Breckpot K 2007 CD83 expression on dendritic cells and T cells: correlation with effective immune responses. European Journal of Immunology 37 686-695. (https://doi.org/10.1002/eji.200636535)

Ahmed A, Singh J, Khan Y, Seshan SV \& Girardi G 2010 A new mouse model to explore therapies for preeclampsia. PLOS ONE 5 e13663. (https://doi.org/10.1371/journal.pone.0013663)

Alter A, Duddy M, Hebert S, Biernacki K, Prat A, Antel JP, Yong VW, Nuttall RK, Pennington CJ, Edwards DR et al. 2003 Determinants of human B cell migration across brain endothelial cells. Journal of Immunology 170 4497-4505. (https://doi.org/10.4049/jimmunol.170.9.4497)

Askelund K, Liddell HS, Zanderigo AM, Fernando NS, Khong TY, Stone PR \& Chamley LW 2004 CD83(+)dendritic cells in the decidua of women with recurrent miscarriage and normal pregnancy. Placenta 25 140-145. (https://doi.org/10.1016/S0143-4004(03)00182-6)

Bock F, Rossner S, Onderka J, Lechmann M, Pallotta MT, Fallarino F, Boon L, Nicolette C, DeBenedette MA, Tcherepanova IY et al. 2013 Topical application of soluble CD83 induces IDO-mediated immune modulation, increases Foxp3+ T cells, and prolongs allogeneic corneal graft survival. Journal of Immunology 191 1965-1975. (https://doi. org/10.4049/jimmunol.1201531)

Bonney EA \& Brown SA 2014 To drive or be driven: the path of a mouse model of recurrent pregnancy loss. Reproduction 147 R153-R167. (https://doi.org/10.1530/REP-13-0583)

Clark DA 2016 Mouse is the new woman? Translational research in reproductive immunology. Seminars in Immunopathology 38 651-668. (https://doi.org/10.1007/s00281-015-0553-x)

Clark DA, McDermott MR \& Szewczuk MR 1980 Impairment of hostversus-graft reaction in pregnant mice. II. Selective suppression of cytotoxic T-cell generation correlates with soluble suppressor activity and with successful allogeneic pregnancy. Cellular Immunology 52 106118. (https://doi.org/10.1016/0008-8749(80)90404-9)

Clark DA, Chaput A \& Tutton D 1986 Active suppression of host-vs-graft reaction in pregnant mice. VII. Spontaneous abortion of allogeneic CBA/J $x \mathrm{DBA} / 2$ fetuses in the uterus of $\mathrm{CBA} / \mathrm{J}$ mice correlates with deficient non-T suppressor cell activity. Journal of Immunology 136 1668-1675.

Clark DA, Chaouat G, Arck PC, Mittruecker HW \& Levy GA 1998 Cytokine-dependent abortion in $\mathrm{CBA} \times \mathrm{DBA} / 2$ mice is mediated by the procoagulant fgl 2 prothrombinase [correction of prothombinase]. Journal of Immunology 160 545-549.

Clark DA, Manuel J, Lee L, Chaouat G, Gorczynski RM \& Levy GA 2004 Ecology of danger-dependent cytokine-boosted spontaneous abortion in the CBA $\times$ DBA $/ 2$ mouse model. I. Synergistic effect of LPS and (TNF-alpha+IFN-gamma) on pregnancy loss. American Journal of Reproductive Immunology 52 370-378. (https://doi.org/10.1111/j.16000897.2004.00237.x)

Eckhardt J, Kreiser S, Dobbeler $M$, Nicolette C, DeBenedette MA, Tcherepanova IY, Ostalecki C, Pommer AJ, Becker C, Gunther C et al. 2014 Soluble CD83 ameliorates experimental colitis in mice. Mucosal Immunology 7 1006-1018. (https://doi.org/10.1038/mi.2013.119)

Hampton AL, Nie G \& Salamonsen LA 1999 Progesterone analogues similarly modulate endometrial matrix metalloproteinase- 1 and matrix metalloproteinase-3 and their inhibitor in a model for long-term contraceptive effects. Molecular Human Reproduction 5 365-371. (https://doi.org/10.1093/molehr/5.4.365)

Harmon AC, Cornelius DC, Amaral LM, Faulkner JL, Cunningham Jr MW, Wallace K \& LaMarca B 2016 The role of inflammation in the pathology of preeclampsia. Clinical Science 130 409-419. (https://doi.org/10.1042/ CS20150702)

Hashimoto H, Eto T, Endo K, Itai G, Kamisako T, Suemizu H \& Ito M 2010 Comparative study of doses of exogenous progesterone administration needed to delay parturition in Jcl:MCH(ICR) mice. Experimental Animals 59 521-524. (https://doi.org/10.1538/expanim.59.521)

Hock BD, Kato M, McKenzie JL \& Hart DN 2001 A soluble form of CD83 is released from activated dendritic cells and B lymphocytes, and is detectable in normal human sera. International Immunology 13 959967. (https://doi.org/10.1093/intimm/13.7.959)

Hoffmann FS, Kuhn PH, Laurent SA, Hauck SM, Berer K, Wendlinger SA, Krumbholz M, Khademi M, Olsson T, Dreyling M et al. 2015 The immunoregulator soluble TACI is released by ADAM10 and reflects B cell activation in autoimmunity. Journal of Immunology 194 542-552. (https://doi.org/10.4049/jimmunol.1402070)

Imada K, Ito A, Itoh Y, Nagase H \& Mori Y 1994 Progesterone increases the production of tissue inhibitor of metalloproteinases-2 in rabbit uterine cervical fibroblasts. FEBS Letters 341 109-112. (https://doi. org/10.1016/0014-5793(94)80250-5)

Jensen F, Muzzio D, Soldati R, Fest S \& Zenclussen AC 2013 Regulatory B10 cells restore pregnancy tolerance in a mouse model. Biology of Reproduction 89 90. (https://doi.org/10.1095/biolreprod.113.110791)

Kretschmer B, Luthje K, Guse AH, Ehrlich S, Koch-Nolte F, Haag F, Fleischer B \& Breloer M 2007 CD83 modulates B cell function in vitro: increased IL-10 and reduced Ig secretion by CD83Tg B cells. PLOS ONE 2 e755. (https://doi.org/10.1371/journal.pone.0000755)

Kretschmer B, Kuhl S, Fleischer B \& Breloer M 2011 Activated T cells induce rapid CD83 expression on B cells by engagement of CD40. Immunology Letters 136 221-227. (https://doi.org/10.1016/j.imlet.2011.01.013)

Krzyzak L, Seitz C, Urbat A, Hutzler S, Ostalecki C, Glasner J, Hiergeist A, Gessner A, Winkler TH, Steinkasserer A et al. 2016 CD83 modulates B cell activation and germinal center responses. Journal of Immunology 196 3581-3594. (https://doi.org/10.4049/jimmunol.1502163)

Kuon RJ, Strowitzki T, Sohn C, Daniel V \& Toth B 2015 Immune profiling in patients with recurrent miscarriage. Journal of Reproductive Immunology 108 136-141. (https://doi.org/10.1016/j.jri.2015.01.007)

Lan Z, Lian D, Liu W, Arp J, Charlton B, Ge W, Brand S, Healey D, DeBenedette M, Nicolette C et al. 2010 Prevention of chronic renal allograft rejection by soluble CD83. Transplantation 90 1278-1285. (https://doi.org/10.1097/TP.0b013e318200005c)

Li DY, Gu C, Min J, Chu ZH \& Ou QJ 2012 Maturation induction of human peripheral blood mononuclear cell-derived dendritic cells. Experimental and Therapeutic Medicine 4 131-134. (https://doi.org/10.3892/ etm.2012.565)

Lin W, Buscher K, Wang B, Fan Z, Song N, Li P, Yue Y, Li B, Li C \& Bi H 2018 Soluble CD83 alleviates experimental autoimmune uveitis by inhibiting filamentous actin-dependent calcium release in dendritic cells. Frontiers in Immunology 9 1567. (https://doi.org/10.3389/fimmu.2018.01567)

Luthje K, Kretschmer B, Fleischer B \& Breloer M 2008 CD83 regulates splenic B cell maturation and peripheral B cell homeostasis. International Immunology 20 949-960. (https://doi.org/10.1093/intimm/dxn054)

Mueller SN \& Germain RN 2009 Stromal cell contributions to the homeostasis and functionality of the immune system. Nature Reviews: Immunology 9 618-629. (https://doi.org/10.1038/nri2588)

Murphy G 2008 The ADAMs: signalling scissors in the tumour microenvironment. Nature Reviews: Cancer 8 929-941. (https://doi. org/10.1038/nrc2459)

Muzzio DO, Soldati R, Ehrhardt J, Utpatel K, Evert M, Zenclussen AC, Zygmunt M \& Jensen F 2014a B cell development undergoes profound modifications and adaptations during pregnancy in mice. Biology of Reproduction 91 115. (https://doi.org/10.1095/ biolreprod.114.122366)

Muzzio DO, Soldati R, Rolle L, Zygmunt M, Zenclussen AC \& Jensen F $2014 b$ B-1a B cells regulate T cell differentiation associated with pregnancy disturbances. Frontiers in Immunology 5 6. (https://doi. org/10.3389/fimmu.2014.00006)

Muzzio DO, Ziegler KB, Ehrhardt J, Zygmunt M \& Jensen F 2016 Marginal zone $\mathrm{B}$ cells emerge as a critical component of pregnancy well-being. Reproduction 151 29-37. (https://doi.org/10.1530/REP-15-0274)

Packhäuser KRH, Roman-Sosa G, Ehrhardt J, Kruger D, Zygmunt M \& Muzzio DO 2017 A kinetic study of CD83 reveals an upregulation and higher production of sCD83 in lymphocytes from pregnant mice. Frontiers in Immunology 8 486. (https://doi.org/10.3389/fimmu.2017.00486)

Pereira JP, Kelly LM \& Cyster JG 2010 Finding the right niche: B-cell migration in the early phases of T-dependent antibody responses. International Immunology 22 413-419. (https://doi.org/10.1093/intimm/ dxq047)

Piccinni MP, Lombardelli L, Logiodice F, Kullolli O, Parronchi P \& Romagnani S 2016 How pregnancy can affect autoimmune diseases progression? Clinical and Molecular Allergy 14 11. (https://doi. org/10.1186/s12948-016-0048-x)

Pinho MP, Migliori IK, Flatow EA \& Barbuto JA 2014 Dendritic cell membrane CD83 enhances immune responses by boosting intracellular calcium release in T lymphocytes. Journal of Leukocyte Biology 95 755762. (https://doi.org/10.1189/jlb.0413239) 
Prechtel AT \& Steinkasserer A 2007 CD83: an update on functions and prospects of the maturation marker of dendritic cells. Archives of Dermatological Research 299 59-69. (https://doi.org/10.1007/s00403007-0743-z)

Qian ZD, Huang LL \& Zhu XM 2015 An immunohistochemical study of CD83- and CD1a-positive dendritic cells in the decidua of women with recurrent spontaneous abortion. European Journal of Medical Research 20 2. (https://doi.org/10.1186/s40001-014-0076-2)

Racicot K \& Mor G 2017 Risks associated with viral infections during pregnancy. Journal of Clinical Investigation 127 1591-1599. (https://doi. org/10.1172/JCl87490)

Raghupathy R, Al-Azemi M \& Azizieh F 2012 Intrauterine growth restriction: cytokine profiles of trophoblast antigen-stimulated maternal lymphocytes. Clinical and Developmental Immunology 2012734865 (https://doi.org/10.1155/2012/734865)

Reinwald S, Wiethe C, Westendorf AM, Breloer M, Probst-Kepper M, Fleischer B, Steinkasserer A, Buer J \& Hansen W 2008 CD83 expression in CD4+ T cells modulates inflammation and autoimmunity. Journal of Immunology 180 5890-5897. (https://doi.org/10.4049/ jimmunol.180.9.5890)

Robertson SA, Care AS \& Skinner RJ 2007 Interleukin 10 regulates inflammatory cytokine synthesis to protect against lipopolysaccharide-induced abortion and fetal growth restriction in mice. Biology of Reproduction 76 738-748. (https://doi.org/10.1095/ biolreprod.106.056143)

Seldon TA, Pryor R, Palkova A, Jones ML, Verma ND, Findova M, Braet K, Sheng Y, Fan Y, Zhou EY et al. 2016 Immunosuppressive human antiCD83 monoclonal antibody depletion of activated dendritic cells in transplantation. Leukemia 30 692-700. (https://doi.org/10.1038/ leu.2015.231)
Starke C, Steinkasserer A, Voll RE \& Zinser E 2013 Soluble human CD83 ameliorates lupus in NZB/W F1 mice. Immunobiology 218 1411-1415. (https://doi.org/10.1016/j.imbio.2013.06.002)

Su LL, Iwai H, Lin JT \& Fathman CG 2009 The transmembrane E3 ligase GRAIL ubiquitinates and degrades CD83 on CD4 T cells. Journal of Immunology 183 438-444. (https://doi.org/10.4049/jimmunol.0900204)

Wilson J, Cullup H, Lourie R, Sheng Y, Palkova A, Radford KJ, Dickinson AM, Rice AM, Hart DN \& Munster DJ 2009 Antibody to the dendritic cell surface activation antigen CD83 prevents acute graftversus-host disease. Journal of Experimental Medicine 206 387-398. (https://doi.org/10.1084/jem.20070723)

Wolenski M, Cramer SO, Ehrlich S, Steeg C, Fleischer B \& von Bonin A 2003 Enhanced activation of CD83-positive T cells. Scandinavian Journal of Immunology 58 306-311. (https://doi.org/10.1046/j.13653083.2003.01303.x)

Zhou LJ \& Tedder TF 1995 Human blood dendritic cells selectively express CD83, a member of the immunoglobulin superfamily. Journal of Immunology 154 3821-3835.

Zhou LJ \& Tedder TF 1996 CD14+ blood monocytes can differentiate into functionally mature CD83+ dendritic cells. PNAS 93 2588-2592. (https://doi.org/10.1073/pnas.93.6.2588)

Received 11 April 2019

First decision 13 May 2019

Revised manuscript received 29 July 2019

Accepted 19 August 2019 